\title{
Algae in the motion: Spatial distribution of phytoplankton in thermally stratified reservoirs
}

\author{
E. Moreno-Ostos ${ }^{1,2}$, L. Cruz-Pizarro ${ }^{2}$, A. Basanta-Alvés ${ }^{3}$, C. Escot $^{3} \&$ D. G. George ${ }^{4}$ \\ ${ }^{1}$ Flumen Research Group. Dept. Ecology. University of Barcelona. Av. Diagonal 645. 08028. Barcelona \\ (Spain) \\ ${ }^{2}$ Water Research Institute. University of Granada. C/Ramón y Cajal, 4. 18071. Granada. (Spain) \\ ${ }^{3}$ Aquatic Ecology Station. EMASESA. Avenida Leonardo da Vinci. 41092, Sevilla (Spain) \\ ${ }^{4}$ Centre for Ecology and Hydrology. Lancaster Environment Centre. Library Avenue, Bailrigg LA1 4AP \\ England (UK) \\ Corresponding Author: emoreno@ub.edu
}

\begin{abstract}
Phytoplankton spatial distribution patterns in four Andalusian reservoirs with different physical characteristics are described and evaluated in this work. Both vertical and horizontal distribution patterns are presented in order to demonstrate that thermally stratified reservoirs are dynamic, complex and heterogeneus ecosystems. Vertically, phytoplankton patchiness was physically controlled by turbulent mixing and light climate and biologically determined by the hydromechanical characteristics of each microalgae functional group. The horizontal distribution of phytoplankton was the result of the interaction between the wind-induced advective transport of water masses and the vertical distribution of each algal group. The precise knowledge of the phytoplankton spatial distribution patterns and their responsible agents constitutes a powerful tool for a limnologicallybased dynamic reservoir management and must be integrated in reservoir water quality monitoring procedures. The use of fastresponse and high-resolution technologies, such as in vivo and in situ spectrofluorimetry, should significantly helps in reaching this objective.
\end{abstract}

Keywords: Reservoir, Phytoplankton, Heterogeneity, Patchiness, Physical-biological coupling, Spectrofluorimetry.

\begin{abstract}
RESUMEN
En este estudio se describen y evalúan algunos de los principales patrones de distribución espacial del fitoplancton en un conjunto de cuatro embalses andaluces de diferentes características físicas. Los patrones de distribución vertical y horizontal del fitoplancton obtenidos demuestran que los embalses térmicamente estratificados constituyen un tipo de ecosistema especialmente dinámico, complejo y heterogéneo. La distribución vertical del fitoplancton estuvo controlada por agentes físicos como la mezcla turbulenta de la columna de agua y el clima lumínico al que son sometidas las algas así como por factores biológicos como las características hidromecánicas de los distintos grupos funcionales de fitoplancton. La distribución de las microalgas en el plano horizontal surge como resultado de la interacción entre el transporte advectivo de las distintas masas de agua inducido por el viento y la distribución vertical de cada grupo algal. El conocimiento preciso de los distintos patrones de distribución del fitoplancton y de los agentes responsables de los mismos constituye una herramienta de especial utilidad para una gestión dinámica y basada en principios limnológicos de los embalses y debe ser integrado en los procedimientos de control de la calidad del agua embalsada. El uso de tecnologías de respuesta rápida y alta resolución de toma de datos, tales como la espectrofluorimetría in vivo e in situ, puede facilitar considerablemente alcanzar este objetivo.
\end{abstract}

Palabras clave: Embalses, Fitoplancton, Heterogeneidad, Manchas, Acoplamiento físico-biológico, Espectrofluorimetría.

\section{INTRODUCTION}

As Professor Ramón Margalef pointed out in his book La Biosfera: entre la termodinámica y el juego (1980), ecosystems constitute a complex organisation structured along two main axis: time and space. Every living organism contributes to the temporal organisation of the whole system with a characteristic time scale and also participates in its spatial organisation as a con- 
sequence of their motility, function and requirements. In nature, populations of most of the species exhibit heterogeneus spatial distributions with organisms agregating where favourable conditions for growth, reproduction and survival are found or accumulating in regions where they are passively transported by water in motion (Begon et al., 1999).

Spatial heterogenity in the distribution of organisms in their habitats is considered a key concept for a number of ecological theories such as competition, species diversity, sucession, evolution, adaptation, parasitism, population genetics, population growth, predator-prey interactions and social behaviour (Legendre \& Fortin, 1989; Wiens, 1989). In addittion, boundaries between "homogeneus" regions in the space are a significant structuring factor for the ecosystems (Allen, 1977; Legendre et al., 1986) especially relevant for their dynamics (Legendre \& Demers, 1984). Moreover, some studies reveal a notable contribution of spatial heterogeneity to the ecosystem stability (Huffaker, 1958; May, 1974; Hassel \& May, 1974; Neill, 1990).

The interaction between the hydromechanical properties of each algal functional group (swimming algae, positively-, negatively- or neutrallybuoyant algae) and the physical conditions of the waterbody (i.e. turbulence, thermal structure, mixing conditions, advective transport and light climate, among others) is responsible for the generation and evolution of the vertical and horizontal algae patchiness (George \& Edwards, 1976; George \& Heaney, 1978; George, 1981a; Moreno-Ostos, 2002; Moreno-Ostos, 2004). In the case of water supply reservoirs, patches of non-desirable or harmful algae (such as Cyanobacteria and some Dinoflagellates) can induce notorious water quality problems increasing water treatment costs.

An adequate and scientifically-based management of the stored water quality requires a profound knowledge of the spatial and temporal dynamics of phytoplankton in reservoirs, taking into consideration their intrinsic heterogeneus character from the appropriate scales and using modern technologies to obtain data series under an optimal spatial and temporal resolution (Moreno-Ostos et al., 2004a; Moreno-Ostos et al., 2005). This is a particularly relevant topic in the case of the reservoirs located in the Mediterranean arid and semiarid region, where water is a scarce resource. In this work we describe spatial distribution patterns of phytoplankton (both in the vertical and horizontal axis) found in four Andalusian reservoirs, and analyze the underlying physical-biological mechanisms that create them. Reservoir Limnology and the study of the spatial distribution of organisms in their habitat are among the main "Margalefian" subjects and, no doubt, the results of our research are inspired on his pioneer studies.

\section{MATERIAL AND METHODS}

\section{Study site}

The spatial distribution of different phytoplankton functional groups is analyzed in four Andalusian reservoirs, with varying physical and morphometrical characteristics (Fig. 1 and table 1). In three of them, we focus on the distribution of phytoplankton groups in the vertical. In El Gergal reservoir we describe both vertical

Table 1. Main morphometrical and light climate characteristics of the studied reservoirs. Principales características morfométricas y de clima lumínico de los embalses analizados

\begin{tabular}{lcccccc}
\hline Reservoir & Location & $\begin{array}{c}\text { Surface } \\
(\mathbf{h a})\end{array}$ & $\begin{array}{c}\text { Volume } \\
\left(\mathbf{h m}^{\mathbf{3}}\right)\end{array}$ & $\begin{array}{c}\text { Maximum depth } \\
\mathbf{( m )}\end{array}$ & $\begin{array}{c}\text { Mean depth } \\
(\mathbf{m})\end{array}$ & $\begin{array}{c}\text { Water transparency } \\
(\mathbf{m})\end{array}$ \\
\hline Quentar & Granada & 41.6 & 13.6 & 100.0 & 32.7 & 6.04 \\
Bermejales & Granada & 561.8 & 102.6 & 48.0 & 18.3 & 3.5 \\
Béznar & Granada & 170.0 & 54.0 & 100.0 & 31.8 & 2.0 \\
El Gergal & Sevilla & 250.0 & 35.0 & 35.0 & 14.0 & 1.7 \\
\hline
\end{tabular}


and horizontal distribution patterns. All surveys were conducted during July and August 2003 and 2004, coinciding with the maximum thermal stability of the water column.

\section{Physical determinations}

The mixed layer depth $\left(Z_{\text {mix }}\right)$ was estimated, from vertical temperature profiles, as the depth of the maximum thermal gradient. The euphotic layer depth $\left(Z_{\text {eu }}\right)$ was determined as in Walker (1980), from Secchi disk depth observations collected with a $20 \mathrm{~cm}$ diameter white disc. Water motions in El Gergal reservoir were characterized using a Nortek Acoustic Doppler Current Profiler (ADCP) and surficial free-running drogues (see George, 1981b and Moreno-Ostos, 2004).

\section{Vertical and horizontal distribution of phytoplankton}

A recently developed fast-response high-resolution in vivo and in situ spectrofluorimetric probe (bbe Fluoroprobe, Moldaenke. Fig. 2) was used to examine the vertical and horizontal distribution patterns of different phytoplankton functional groups in the studied reservoirs. The probe directly measures total Chlorophyll- $a$ concentration in the water and the fraction corresponding to four different functional groups of algae (Chlorophyceae, Cyanobacteria, Diatoms and Cryptophytes). To differentiate functional groups of phytoplancton the bbe Fluoroprobe uses 5 Light Emiting Diodes (LEDs) for fluorescence excitation. The LEDs emit pulsed light at selected wavelenghts $(450 \mathrm{~nm}, 525 \mathrm{~nm}, 570 \mathrm{~nm}$,
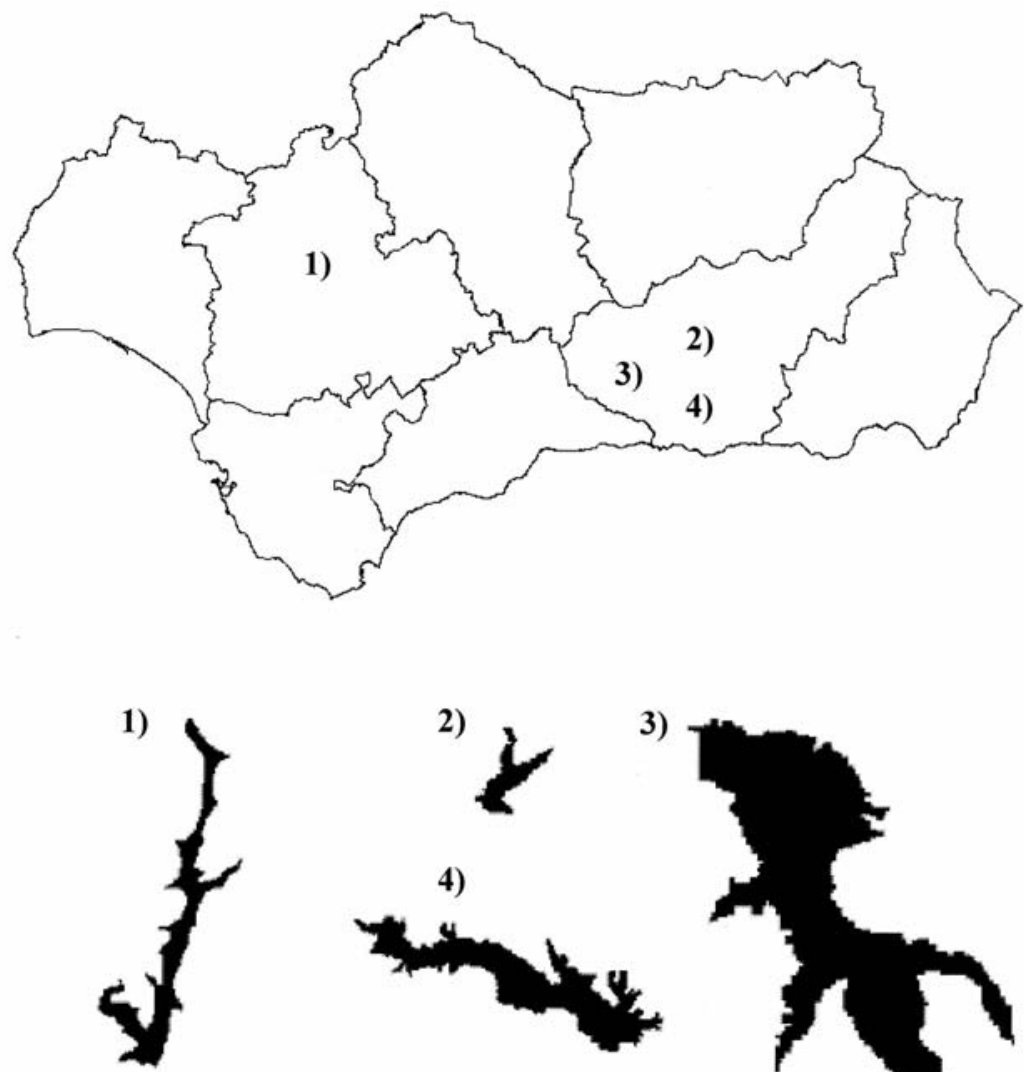

2)

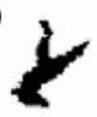

4)

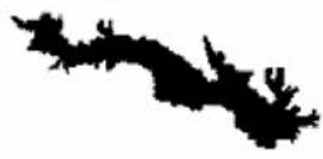

3)

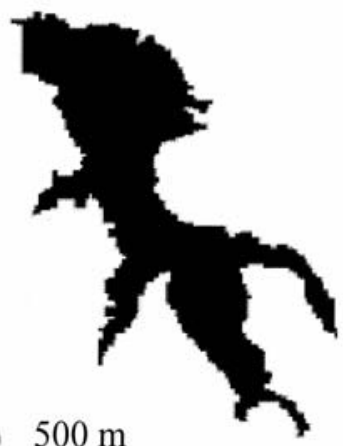

Figure 1. Location and morphology of the studied reservoirs 1) El Gergal reservoir; 2) Quentar reservoir; 3) Bermejoles reservoir; 4) Béznar reservoir. (Andalusia map not to scale.) Localización y morfología de los embalses estudiados 1) Embalse de El Gergal

2) Embalse de Quentar; 3) Embalse de Bermejoles; 4) Embalse de Béznar. (El mapa de Andalucía no es a escala.) 
$590 \mathrm{~nm}$ and $610 \mathrm{~nm}$ ) while fluorimetric emission is measured at $680 \mathrm{~nm}$ by photomultiplier at an angle of 90 degrees to the exciting light source and directly transformed to Chl- $a$ concentration by the bbe Fluoroprobe 1.4 software. The probe is also equiped with a temperature sonde so coupled thermal structure and algal distribution profiles/transects can be displayed.

In order to describe the vertical distribution of phytoplankton, free-falling mode vertical

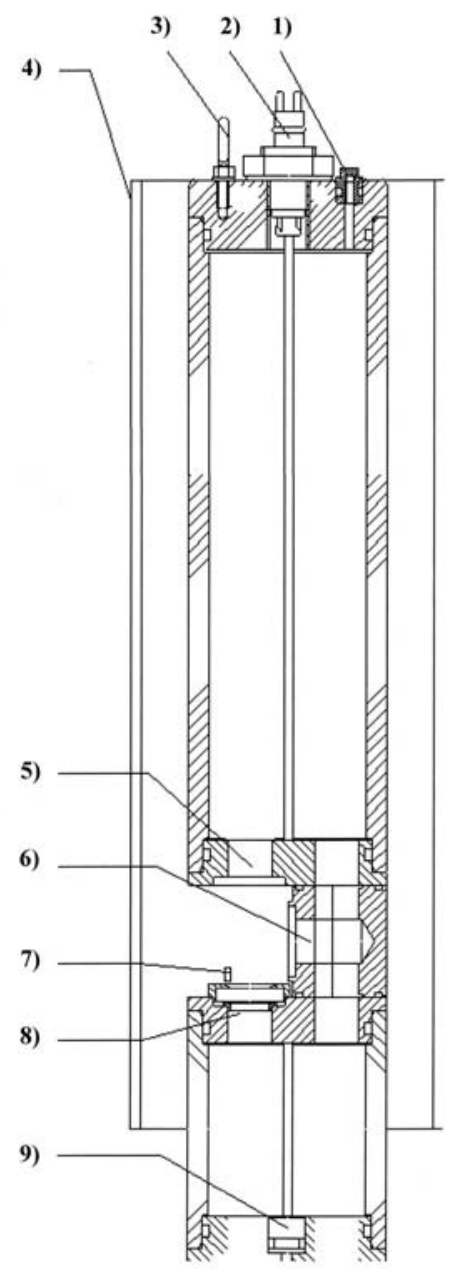

Figure 2. bbe Fluoroprobe components (modified from bbe Moldaenke user manual). 1) Screw. 2) Connector. 3) Eyelet. 4) Screen. 5) Detector window. 6) LED window. 7) Temperature sensor. 8) Transmission window. 9) Preassure sensor Componentes del bbe Fluoroprobe (modificado del manual de usuario de bbe Moldaenke). 1) Tornillería de sujección. 2) Conector. 3) Arándela de sujección. 4) Pantalla de protección. 5) Ventana de detección. 6) Ventana de LEDs. 7) Sensor de temperatura. 8) Ventana de transmisión. 9) Sensor de presión. spectrofluorimetric profiles were collected from fixed sampling stations located at the maximum depth points of each reservoir. The horizontal distribution of algae in El Gergal reservoir, on the other hand, was characterized from a set of surficial (1 meter depth) spectrofluorimetric data collected at a grid of up to 30 GPS-georeferenced sampling stations. Due to the reduced size of the reservoir and the use of a fast-response probe the time spent to complete a whole horizontal survey was minimized and the collected data can be considered as synoptic.

For further details on bbe Fluoroprobe technical characteristics and its applications to study the phytoplankton spatial dynamics in reservoirs see Beutler et al. (2002) and Moreno-Ostos (2004).

\section{RESULTS}

\section{Vertical patchiness}

Figure 3 shows the vertical distribution of temperature, total Chl- $a$ and the biomass corresponding to different algae functional groups in the studied reservoirs. The described patterns are closely related to the physical (light climate, mixing regime) and the biological (composition of the phytoplankton community) characteristics of each ecosystem.

In Quentar, a deep and meso-oligotrophic reservoir, $Z_{\text {mix }}$ and $Z_{\text {eu }}$ are similar in magnitude (16.0 meters and 16.3 meters respectively). As a result, there exists a marked Deep Chlorophyll Maximum (DCM) located at the depth of the thermocline, i.e. 16 meters. Phytoplankton finds in the thermocline an appropriate site for growth and development since light levels are adequate for photosynthesis, nutrients from the hypolimnion are frequently entrained into the epilimnion and the stability is large. As for the composition of the phytoplankton community, Diatoms and Cryptophytes -two light-stress tolerant algae groups- are the most abundant groups. While Diatoms were mainly located just above the thermocline, the Cryptophytes (more tolerant to reduced light levels) were mostly below it. 

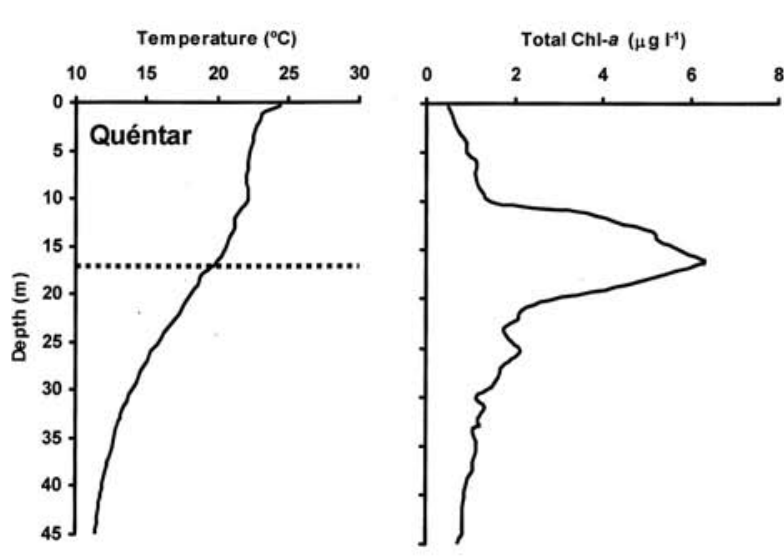

Different algae functional groups biomass
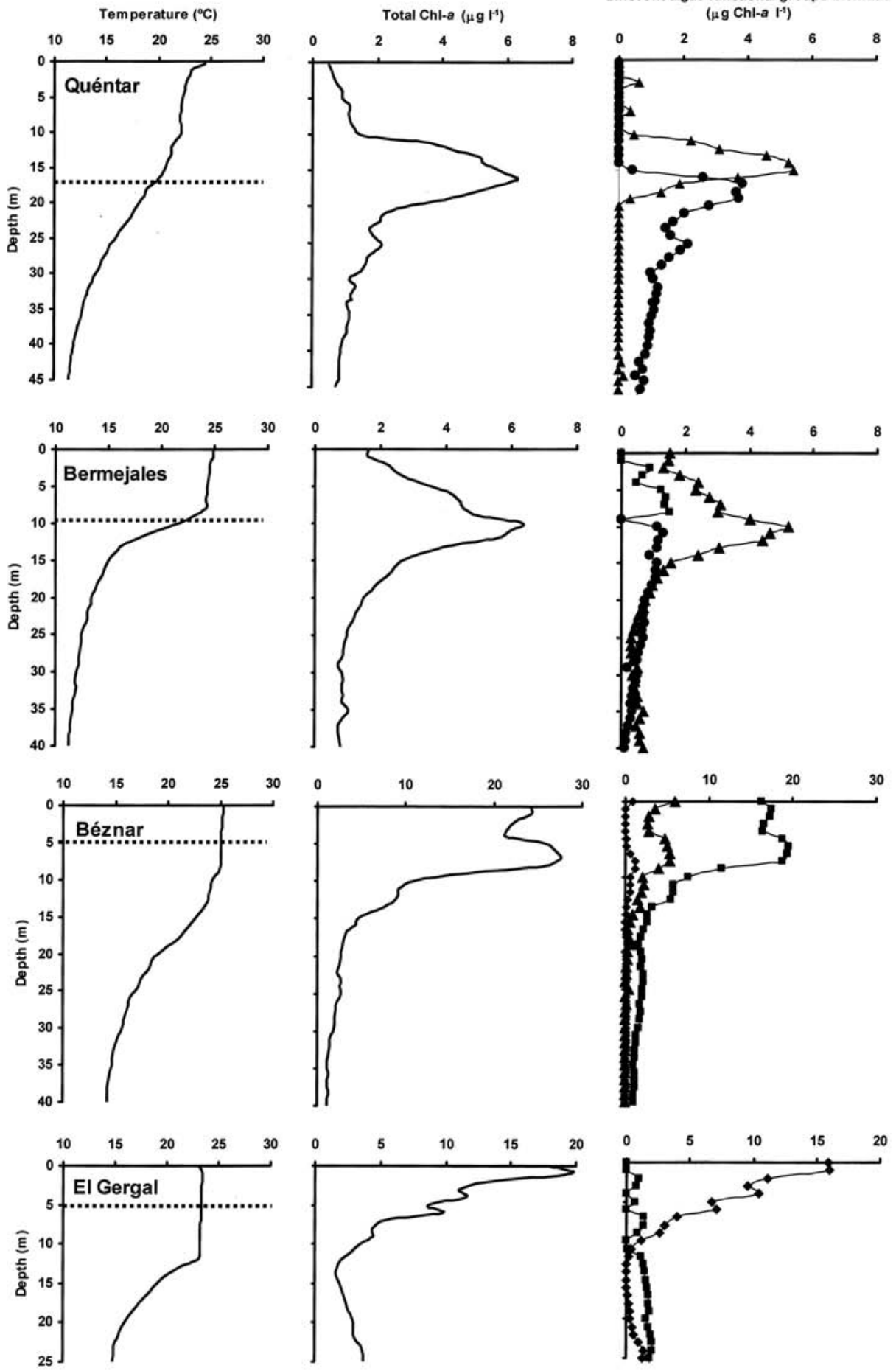

Figure 3. Vertical distribution of temperature (left), total Chl- $a$ (centre) and different phytoplankton functional groups (right) in the studied reservoirs. Horizontal dotted line represent the euphotic layer depth. Distribución vertical de la temperatura (izquierda), Chl-a total (centro) y distintos grupos funcionales del fitoplancton (derecha) en los embalses estudiados. La línea de puntos horizontal representa la profundidad de la zona eufótica. 
Light attenuation was higher in the mesotrophic Bermejales reservoir than in Quentar and the thermocline was shallower (around 10 meters). Here, $Z_{\text {mix }}$ and $Z_{\text {eu }}$ also have similar values (10.0 meters and 9.5 meters respectively). The vertical profile of Chl- $a$ shows a DCM at $10 \mathrm{~m}$. Chlorophytes, Diatoms and Cryptophytes were the main functional groups at the time when the profile was taken. As in Quentar, the Diatoms and Cryptophytes were most abundant in the DCM region. Chlorophytes, on the other hand, are green algae demanding higher light levels and were consequently detected only in the upper layers of the water column.

The thermal structure of Béznar, an eutrophic reservoir, at the time when the profile was taken, was characterised by a relatively shallow diel thermocline located 8 meters below the free surface and a deeper and more stable seasonal thermocline at 18 meters. The bottom of the euphotic zone was estimated to be around
5.5 meters depth. As a consequence, maximum Chl- $a$ concentration was found around the diel thermocline, where settling algae were accumulated. The intense and frequent wind-induced turbulent mixing events recorded in this reservoir (Rueda, unpublished data) allow the algae to enter from this main patch to the euphotic zone thus ensuring their survival (Margalef, 1983). The vertical distribution pattern was similar for the three phytoplankton groups found in the reservoir (Chlorophytes, Diatoms and Cyanobacteria).

The final study case corresponds to El Gergal reservoir $\left(Z_{\text {mix }}=12.0\right.$ meters; $Z_{\text {eu }}=5.0$ meters $)$. In this ecosystem, the dominance of positivelybuoyant Cyanobacteria at the time when the profile was taken induced the formation of an intense surficial algal patch mainly composed by Aphanizomenon sp., while the neutral-buoyant Chlorophytes remained randomly distributed along the water column.

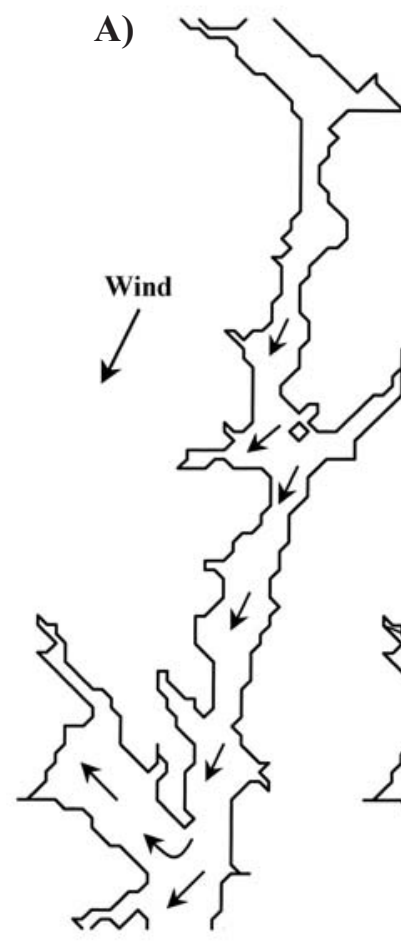

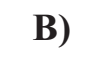

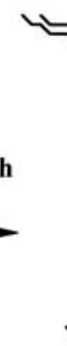

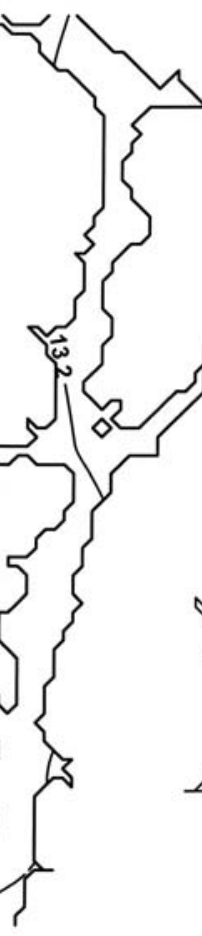

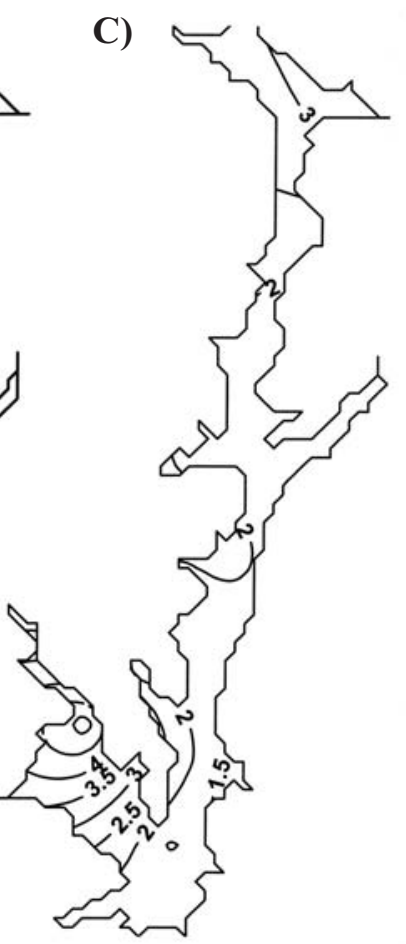

Figure 4. Observed surficial hydrodynamics (A) and simultaneous horizontal variations in water temperature $\left({ }^{\circ} \mathrm{C}\right)(\mathrm{B})$ and $\mathrm{Chl}-a$ $\left(\mu \mathrm{g}^{-1}\right)(\mathrm{C})$ under the influence of a Northeast wind. Note that arrows just show wind and current direction and are not proportional to velocity. Hidrodinámica superficial observada (A) y variación simultánea en el plano horizontal de la temperatura del agua $\left({ }^{\circ} \mathrm{C}\right)(B)$ y de Chl-a $\left(\mu \mathrm{gl}^{-1}\right)$ (C) bajo la acción de vientos de componente Noreste. Los vectores sólo indican las direcciones predominantes adoptadas por el viento y la corriente superficial y no son proporcionales a su velocidad. 

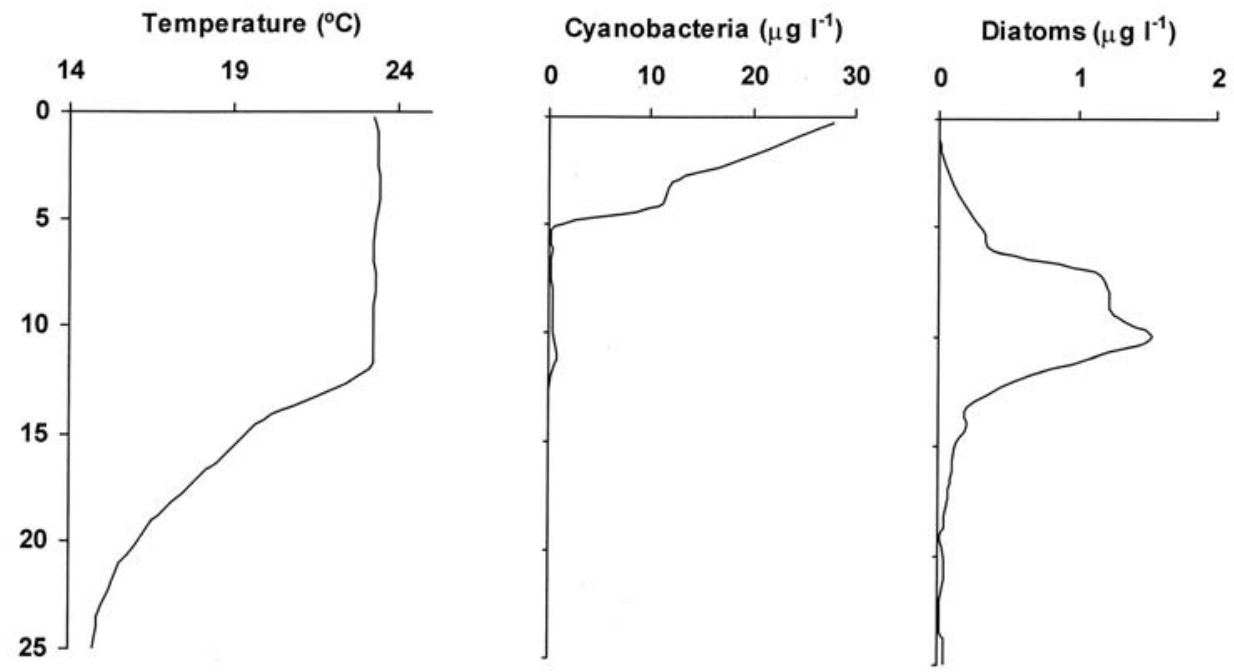

Figure 5. Vertical distribution of temperature $\left({ }^{\circ} \mathrm{C}\right)$, Cyanobacteria biomass $\left(\mu \mathrm{g}^{-1}\right)$ and Diatoms biomass $\left(\mu \mathrm{g} 1^{-1}\right)$ during the late summer 2003 extensive survey in El Gergal reservoir. Distribución vertical de temperatura $\left({ }^{\circ} \mathrm{C}\right)$, biomasa de Cianobacterias ( $\mu \mathrm{g}$

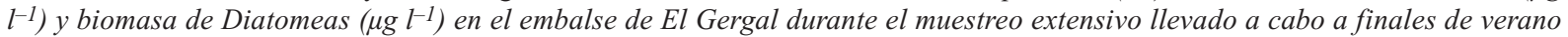
de 2003.

\section{Horizontal patchiness}

During summer 2003 and 2004 a series of data collection campaigns were conducted in El Gergal in order to describe the horizontal distribution of phytoplankton in a thermally stratified reservoir and to analyze the mechanisms that were responsible for the spatial variability of phytoplankton abundance. In a first survey we studied the role of wind-induced water movement on the physical (water temperature) and biological (total Chl- $a$ concentration) horizontal patchiness in the ecosystem. During a second survey, we focused on the differencial Cyanobacteria and Diatoms horizontal distribution as induced by the action of a prevailing North wind. Results from both surveys are presented below.

The role of wind-induced water movement on the horizontal distribution of temperature and total Chl-a

Under the influence of a constant wind of $1.2 \mathrm{~ms}^{-1}$ average module blowing from Northeast $\left(60^{\circ}\right)$ free-running drogues topographical monitoring revealed the existence of a main surficial water current moving from North to South and characterised by a marked gyre into the Cantalobos bay (Fig. 4a).

The horizontal distribution of water temperature was consistent with this hydrodynamic behaviour and the warmer water masses were retained into the bay and along the West shore of the reservoir (Fig. 4b).

Algal biomass acted as a passive tracer of surficial water movement and remained accumulated in the Cantalobos Bay, generating also some patches in the West shore associated to the higher temperature areas (Fig. 4c).

\section{The impact of North wind on the horizontal} distribution of Diatoms and Cyanobacteria

During the survey, wind (blowing from North with an average module of $2.5 \mathrm{~ms}^{-1}$ ) was the only factor inducing movement in the water mass. Figure 5 shows the vertical distribution of temperature, Cyanobacteria and Diatoms during the sampling. Thermal structure was characterised by a marked thermocline at 12 meters depth. Cyanobacteria were detected in the upper layers of the water column, while settling Diatoms were found deeper in the water column and mainly above the thermocline. 
The hydrodynamical behaviour of the reservoir under such circumstances is shown in figure 6 . Our ADCP records revealed wind-driven surface currents from North to South and deeper return currents above the thermocline. The horizontal distribution of phytoplankton (Fig. 7) was a result of the interaction between vertical patchiness and water-mass displacements at different depths. Positively-buoyant Cyanobacteria were passively transported by surface currents to the South region of the reservoir, accumulating around the dam. By contrast, the negativelybouyant Diatoms were selectively transported to the riverine region of El Gergal (North) by the deep recirculating currents, where they emerged and agregated due to the effect of upwelling currents and the increasing turbulence (Moreno-Ostos, 2004). This conveyor belt hydrodynamical mechanism for the generation of phytoplankton patchiness has previoulsly been documented by George \& Edwards (1976).

\section{Horizontal velocity $\left(\mathrm{cm} \mathrm{s}^{-1}\right)$}

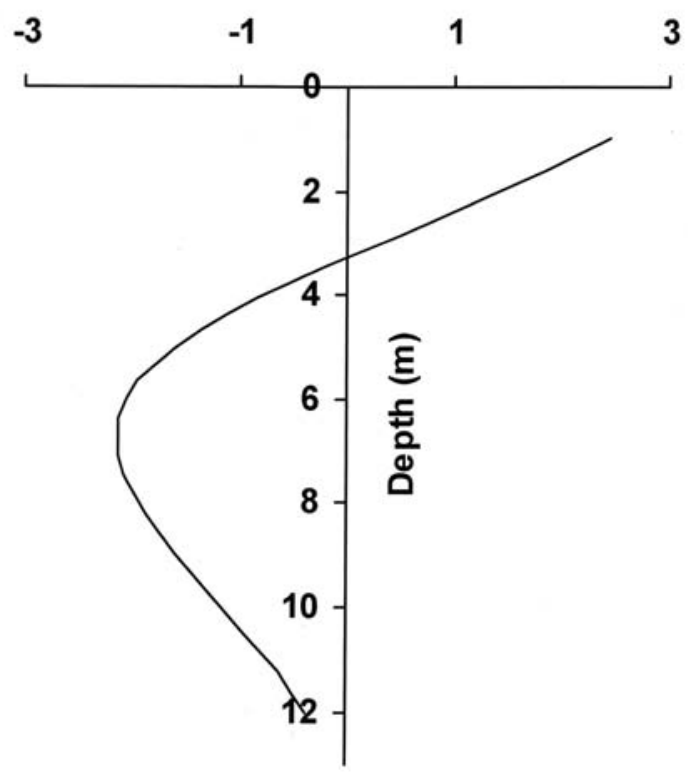

Figure 6. Velocity field (horizontal component) corresponding to the epilimnion of El Gergal reservoir as measured using ADCP. Positive values mean water moving from North to the South. Negative values mean water moving from South to the North. Campo de velocidades (componente horizontal) correspondiente al epilimnion del embalse de El Gergal determinado mediante ADCP. Valores positivos indican desplazamientos del agua de Norte a Sur. Valores negativos indican desplazamientos del agua de Sur a Norte.

\section{DISCUSSION}

The results presented in this paper show that thermally stratified reservoirs of all trophic states must be considered as spatially heterogeneus and complex ecosystems, both in the vertical and horizontal dimensions.

From the clear-water reservoirs characterised by a Deep Chlorophyll Maximum to the more turbid ones, in which positively-buoyant algae agregate in the upper layers of the water column, phytoplankton adopts a whole gradient of heterogeneus (patchy) vertical distribution patterns. Under non-regulated hydraulic conditions (i.e absence of selective withdrawal events or water transfers from/to other reservoirs) phytoplankton vertical distribution is the result of the interaction between physical agents $\left(Z_{\text {mix }}: Z_{\text {eu }}\right)$ and the buoyancy capacities of each algal functional group.

As suggested by Kullemberg (1978) and demonstrated for El Gergal reservoir study cases, algae vertical patchiness coupled with the

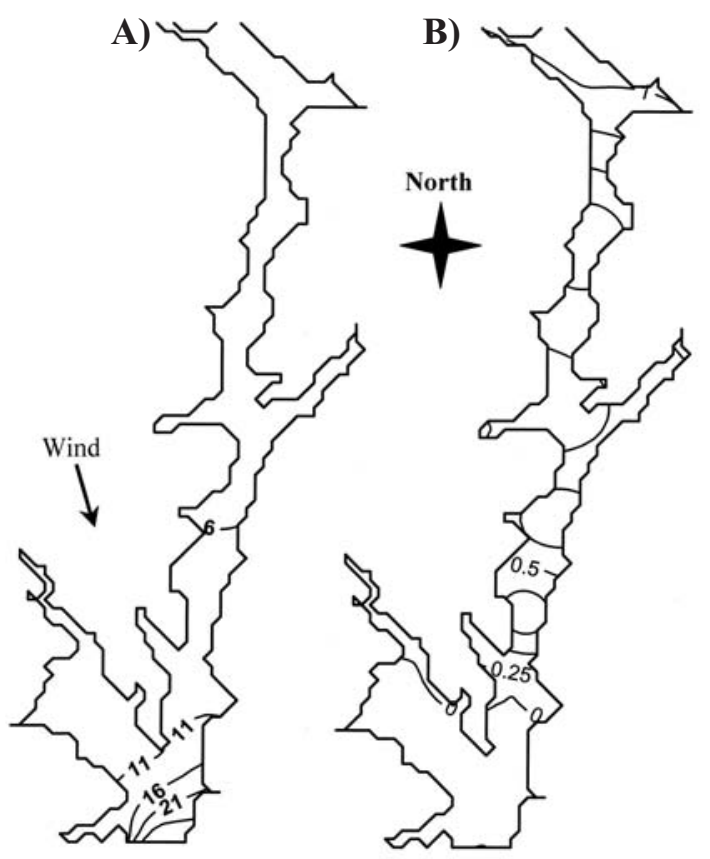

Figure 7. The horizontal distribution of Cyanobacteria (A) and Diatoms (B) in El Gergal reservoir. Algal biomass values expressed in $\mu \mathrm{g}^{-1}$ Distribución vertical de Cianobacterias (A) y Diatomeas (B) en el embalse de El Gergal. Valores de biomasa algal expresados en $\mu \mathrm{g} l^{-1}$. 


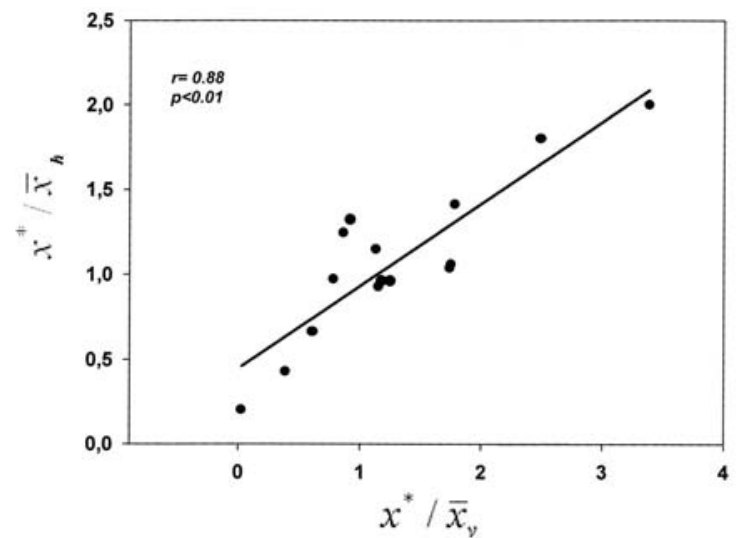

Figure 8. Total Chl- $a$ vertical-horizontal coupling in El Gergal reservoir (from Moreno-Ostos, 2004). Acoplamiento entre la distribución vertical y horizontal de la Chl-a total en el embalse de El Gergal (tomado de Moreno-Ostos, 2004).

wind-induced water movement at different depths resulted in the generation of heterogeneus horizontal distribution of phytoplankton. In addition, the different algae functional groups constitute differential and dynamical patches, each one having their own size, location and transport routes (Moreno-Ostos, 2004).

Previous studies on the spatial distribution of plankton in lakes and reservoirs (George \& Edwards, 1976; Moreno-Ostos, 2004) have revealed the existence of an intense verticalhorizontal coupling in microalgae patchiness. Figure 8 represents the correlation between vertical and horizontal phytoplankton patchiness in El Gergal reservoir during a two years field study (Moreno-Ostos, 2004). In this figure, algal patchiness was expressed as the coefficient between mean crowding and total Chl- $a$ average values, following George \& Edwards (1976). Based on similar observations, Reynolds (1984) points out that phytoplankton horizontal patchiness can be estimated from the vertical distribution of algae in a downwind sampling station and the appropriate morphometrical and meterological data. According to that, reservoir managers can approximate the degree of horizontal patchiness from a reduced number of vertical profiles, a detailed bathimetry of the reservoir and meteorological records, thus making possible to integrate horizontal heterogeneity in their monitoring procedures with minimal increases in time and money costs.
In the same context, our results demonstrate that surface water temperature horizontal distribution can be considered as an adequate surrogate of reservoir surficial hydrodynamics. Thus, extensive water temperature surveys along the horizontal plane of the system could be used by reservoir managers as an appropriate and non-expensive methodology in order to estimate advective processes involved in the formation and transport of phytoplankton horizontal patchiness.

The precise knowledge of the phytoplankton vertical and horizontal distribution patterns under different biological, physical and meteorological conditions represent a valuable tool in hands of reservoir managers. It is essential for the adequate design of selective withdrawal strategies and water transfer operations and for the optimal selection of sampling stations and depths in water quality monitoring surveys (Moreno-Ostos et al., 2004b).

Additionally, the integration of the spatial heterogeneity of phytoplankton in dynamic reservoir modelling would improve the quality and precission of simulations and predictions, thus advancing in the application of this kind of tools for a scientifically-based reservoir management.

To adequately achieve these objectives it is essential to incorporate modern high-resolution technologies both for phytoplankton and hydrodynamical monitoring. The combination of in vivo and in situ spectrofluorimetry and ADCP represents a powerful and efficient device for the analysis of physical-biological coupling.

Fee (1976) alerts on the necessity of taking into consideration the spatial distribution of Chl- $a$ in plankton dynamic studies and points out that estimations of total Chl- $a$ derived from just one vertical profile in the deepest area of the lake often presents errors of $25 \%-40 \%$. In this context we encourage reservoir managers to incorporate in their routinary water quality monitoring procedures the development of extensive samplings on the vertical and horizontal planes of the system, especially during the thermal stratification period, when phytoplankton vertical and horizontal patchiness becomes more intense (Moreno-Ostos, 2004). 


\section{ACKNOWLEDGEMENTS}

This study has been partly funded by the projects UE-LIFE $98 \mathrm{ENV/UK/000607;} \mathrm{CICYT}$ HI99/0836 and CICYT REN 2003-03038. Special thanks to the University of Granada Research Council for funding E Moreno-Ostos Postdoctoral position in the University of Barcelona. Authors would also like to thank the staff of EMASESA for their assistance in the field sampling campaigns in El Gergal reservoir and EMASAGRA for their help in Quentar reservoir. Dr. C. Escot and Dr. F.J. Rueda contributed with valuable comments and suggestions along all the study.

\section{REFERENCES}

ALLEN, T. F. H. 1977. Scale in microscopical algal ecology: a neglected dimension. Phycologia, 16: 253-257.

BEGON, M., J. L. HARPER \& C. R. TOWNSEND. 1999. Ecología. $3^{\text {rd }}$ ed. Omega. Barcelona. 984 pp.

BEUTLER, M., B. MEYER, C. MOLDAENKE, C. LÜRING, M. MEYERHÖFER, V. D. HANSEN \& H. DAU. 2002. A fluorometric method for the differentiation of algal populations in vivo and in situ. Photosynth. Res., 72: 39-53.

FEE, E. J. 1976. The vertical and seasonal distribution of chlorophyll in lakes of the Experimental Lakes Area, northwestern Ontario: implications for primary production estimates. Limnol. Oceanogr., 21(6): 767-783.

GEORGE, D. G. 1981a. Zooplankton patchiness. Rep. Freshwater. Biol. Ass., 49: 32-44.

GEORGE, D. G. 1981b. Wind-induced water movements in the South basin of Windermere. Freshwater. Biol., 11: 37-60.

GEORGE, D. G. \& R. W. EDWARDS. 1976. The effect of wind on the distribution of Chlorophyll $a$ and crustacean plankton in a shallow eutrophic reservoir. J. Appl. Ecol., 13: 667-690.

GEORGE, D. G. \& S. I. HEANEY. 1978. Factors influencing the spatial distribution of phytoplankton in a small productive lake. J. Ecol., 66:133155.

HASSELL, M. P. \& R. M. MAY. 1974. Aggregation of predators and insect parasites and its effect on stability. J. Anim. Ecol., 43: 567-594.
HUFFAKER, C. B. 1958. Experimental studies on predation: Dispersion factors and predator-prey oscillations. Hilgardia, 27: 343-383

KULLENBERG, G. E. B. 1978. Vertical processes and the vertical-horizontal coupling. In: Spatial Pattern in Plankton Communities. J. H. Steele (ed.): 43-71. Plenum Press. New York and London.

LEGENDRE, L. \& S. DEMERS. 1984. Towards dynamic biological Oceanography and Limnology. Can. J. Fish. Aquat. Sci., 41: 2-19.

LEGENDRE, L., S. DEMERS \& D. LEFAIVRE. 1986. Biological production at marine ergoclines. In: Marine interfaces ecohydrodynamics. Nihoul, J.C. (Ed.): 1-29. Elsevier. Amsterdam.

LEGENDRE, P. \& M. J. FORTIN. 1989. Spatial pattern and ecological analysis. Vegetatio, 80: 107138.

MARGALEF, R. 1980. La Biosfera: entre la termodinámica y el juego. Omega. Barcelona. 136 pp.

MARGALEF, R. 1983. Limnología. Ed. Omega, S.A. Barcelona. $1010 \mathrm{pp}$.

MAY, R. M. 1974. General Introduction, In: Ecological Stability. M. B. Usher \& M. H. Williamson (eds.):1-15. Princeton University Press, Princeton.

MORENO-OSTOS, E. 2002. Patrones de distribución espacial del fitoplancton en sistemas acuáticos. Research Project. University of Granada $75 \mathrm{pp}$.

MORENO-OSTOS, E. 2004. Spatial dynamics of phytoplankton in El Gergal reservoir (Seville, Spain). Ph.D. Thesis. University of Granada. $354 \mathrm{pp}$.

MORENO-OSTOS, E., L. CRUZ-PIZARRO, C. ESCOT, A. BASANTA-ALVÉS \& D. G. GEORGE. 2004a. Using in vivo fluorometry and Acoustic Doppler Current Profiler (ADCP) to describe the mechanisms responsibles for the spatial distribution of phytoplankton in a water supply reservoir (El Gergal, Spain). Proceedings of the XXIX SIL Congress. Lahti (Finland). $461 \mathrm{pp}$.

MORENO-OSTOS, E., D. G. GEORGE, C. ESCOT, A. BASANTA-ALVÉS \& L. CRUZ-PIZARRO. 2004b. Distribución espacial del fitoplancton: reflexiones desde la Directiva Marco del Agua. Actas del XII Congreso de la Asociación Española de Limnología y IV Congreso Ibérico de Limnología. Porto (Portugal). 117 pp.

MORENO-OSTOS, E; L. CRUZ-PIZARRO, F. RUEDA; C. ESCOT \& A. BASANTA-ALVÉS. 
2005. Escalas espaciales y temporales en el estudio de embalses: relevancia para la investigación y gestión de los recursos hídricos. In: Actas del V Simposio del Agua en Andalucía Vol. 2. Instituto Geológico y Minero de España (ed.).: 881-890

NEILL, W. E. 1990. Induced vertical migration in copepods as a defence against invertebrate predation. Nature, 345: 524-526.
REYNOLDS, C. S. 1984. The ecology of freshwater phytoplankton. Cambridge University Press. Cambridge. 396 pp.

WALKER, T. A. 1980. A correction to the Poole and Atkins Secchi disc/light-attenuation formula. $J$. Mar. Biol. Ass. U.K., 60: 769-771.

WIENS, J. A. 1989. Spatial scaling in ecology. Funct. Ecol., 3: 385-397. 